\title{
Leadership and Organizational Factors as Predictors of Employees Organisational Commitment in Nigeria: An Empirical Analysis
}

\author{
Gabriel Aunde Akinbode (Ph.D) (Correspondence Author) \\ Department of Psychology, Faculty of Social Sciences \\ University of Lagos, Nigeria \\ Tel: 234-08-02-310-7609 E-mail: bodegabriel@yahoo.com \\ Oni Bamikole Fagbohungbe (Ph.D) \\ Department of Psychology, Faculty of Social Sciences \\ University of Lagos, Nigeria \\ Tel: 234-08-03-301-4389 E-mail: kolefagbo@yahoo.com
}

Received: May 22, 2012

doi:10.5430/bmr.v1n2p69
Accepted: June 6, 2012

Online Published: June 8, 2012

URL: http://dx.doi.org/10.5430/bmr.v1n2p69

\begin{abstract}
This study examined the relationship between leadership-behaviour and organizational factors as predictors of workers organizational commitment. Ex-Post-Factor research design was employed. A total number of 504 workers selected from private and public sector organizations located in Lagos and Abuja in Nigeria participated in the study. The study was anchored on Graen and Scandura Leader-member exchange theory. It was hypothesized that job tenure, management cadre and organizational type will significantly predict workers' organizational commitment. Also, workers who perceived their bosses to be high on interpersonal relations and emancipatory leadership behaviour will identify more with their organization, demonstrate high loyalty and show high commitment to their organizations. Results revealed a positive progression in the influence of organizational factor on organizational commitment variables. Specifically, junior workers reported more commitment compared to senior management level workers for at least 1.03 times. Interpersonal relations contributed about $19.9 \%$ of the total variance of the observed job indentification and $28.8 \%$ to workers' job loyalty, and $19.3 \%$ to organizational commitmen respectivelyt. Emancipatory leadership-behaviour contributed $17.2 \%$ and $10.2 \%$ to loyalty and organizational commitment. Autocratic/control contributed $19.3 \%$ to the observed variance in job involvement. Meanwhile, autocratic/control leadership-behavior accounted for about $15.4 \%$ of workers' disloyalty to their organizations. Findings in the study were discussed in the light of emergent literatures on leadership and organizational research.
\end{abstract}

Keywords: Identification, Involvement, Loyalty, Leadership, Organizational factors

\section{Introduction}

As twenty-first century vista of knowledge continues, life at work continues to change in many ways. Competitive organizational environments, demographically diverse workforces, technological advances and unending wave of newness, are just a few of those changes. These changes increasingly require flexibility and excellence from workers, because availability of equipment and machines in any work setting no longer guarantees performance (Helgesen, 1990). Performance requires among other things; functional leadership, knowledge, skills, abilities and other human characteristics that all workers should possess for optimal organisational functioning (Limerick, 1992). In the light of seeming declining organizational effectiveness that is ravaging private and public sector workplace, how can excellence from employees be encouraged? Even though there are many aspects of an employees' work life that do contribute to performance, one of the most important concerns is the relationship between employees and their managers/supervisors. Specifically, the manner in which managers/supervisors ask employees to undertake tasks may result in critical differences in employees' performance, commitment and involvement. As part of human characteristics, every man is endowed with some measures of dispositional tendencies which are wrapped-up in our personality (Fagbohungbe \& Longe, 2003). These tendencies unfold as human beings continue to interact with one another. The tendency to demonstrate appropriate behaviour in any social interaction therefore depends strongly on 
the quality of the interaction. In the work setting for example, the individual chooses to identify with his job, and demonstrate absolute loyalty. On the other hand, the individual may withhold appropriate behaviour, depending on the perception of the quality of the psychological relationship between him, colleagues and particularly his superior/manager (Ahmed, 1985; Alo, 1982; Esigbone, 2000; Foke, 2001; Dunham-Taylor, 2000; Kraut, 1970; Eze, 1988; Eze, 1994; Fagbohungbe, 2009).

In line with global attention in this direction Suar, Tewari and Chaturbed (2006) have shown that subordinates' perception of leadership style has a significant relationship with commitment to the organization and job satisfaction. Several major studies have found a positive relationship between these variables (e.g. leadership and satisfaction etc). These studies includes that of scholars such as Newman (1974); Porter, Campon and Smith (1976), Mathieu and Zajack (1994) and Wilson (1995). However, research evidence in Nigeria, as far as this relationship is concerned, has been quite inconclusive and reveals mixed evidence (Eze, 1983; Fagbohungbe, 1981; Esigbone, 2000).

\subsection{The problem}

Today, work organizations in Nigeria "cultivate and fertilize" negative reactions among workers due to "leadership failure'. Managers/supervisors tend to use top-down, command and control management techniques, which have caused bosses to develop failed working relationships, whivh in turn failed to foster trust, respect and confidence among their staff. This leadership atmosphere is suspected to demean, disrespect and demotivate employees, thereby leading to seeming erosion of motivational tendencies, organisational commitment and job involvement (Fagbohungbe, 1981; Eze, 1985; Eze, 1988; Eze, 1994; Alarape \& Akinlabi, 2000). Lack of recognition of individual performance, lack of effective communication, innovation and general mistrust toward managers/supervisors are suspected rexperiences of employees in the work place as due to leadership failure (McIntire, 2002; Howard \& Howard, 2000; Suar, Taweri \& Chaturbedi, 2006). In order to protect themselves probably, the average Nigerian worker is suspected to have become apathetic toward the workplace. Where opportunities are not available to quit the organization, such worker's become emotionally or mentally withdrawn from the organization.

In recent times it appears that optimal organisational functioning has dropped significantly, compared to what was obtainable in the past. The capacity of an average Nigerian worker to give extra discretionary contributions that are neither required nor expected without "rubbing" his/her hands has almost become a tall dream. Individual worker chooses to withhold loyalty by engaging in sharp practices as a direct result of his/her perception of negative experiences in the workplace.

Given this background, it is suspected on one hand that behaviours of managers and supervisors (or better still management style/approach) and the way such behaviours are perceived by subordinates is affect the job behaviours of workers. If Nigerian workers are given the opportunity to describe their bosses' leadership or supervisory behaviour, many would probably describe them as corrupt opportunist -"Monkey dey work baboon dey chop". This suspected perception is inimical to favourable disposition to work and as a result has serious implications for followership. As we speak, it appears that only a few supervisors/managers tend to gain little effort of their subordinates, because of the way and manner in which people are led and managed in the workplaces. These perceptions have the potential of discouraging workers from readiness and capacity to make significant contributions to organisational success. They also have the tendency of being reflected in subordinates' general attitude to work, motivational tendencies etc.

This study recognised the fact that organizational variables such as job status/cadre, tenure, reward system, organizational type and personal-social aspect of traditional work environments are also responsible in part for the observed job behaviour (see Fagbohungbe 2002; Eze, 1985) Nevertheless, available literature reveal mixed evidence about how subordinates' perceived leader-behaviours and organizational factors would influence job behaviour negatively or positively (Fagbohungbe, 1981; Eze, 1985; Alarape \& Akinlabi, 2000; Howard \& Howard, 2000; Udegbe, Okuramen \& Shenge, 2001; Nikolaou \& Robertson, 2001; Suar, Taweri \& Chaturbedi, 2006).

\subsection{Objectives of the Study}

The objectives of the study were to:

1) Investigate the influence organizational factors on various facets of organizational commitment variables.

2) Investigate the influence of sub-ordinates' perceptions of bosses' leadership-behaviour on various facets of organizational commitment variables. 


\subsection{Orgaisational Commitment}

Organizational commitment is defined as the "relative strength of an individual's identification and involvement in a particular organization" (Mowday, Porter, \& Steers, 1982), and a "psychological link between an employee and his or her organisation that makes it less likely that the employee will be willing to voluntarily leave the organisation" (Allen \& Meyer, 1996). Hence, paving the way for employees to be satisfied with the organization in which they work can be said to be as crucial as providing goods and services (Çöl, 2004). Organisational commitment is of considerable interest to psychologists because there is strong evidence of links between high levels of commitment and favourable organizational outcomes. At the individual level of analysis, commitment predicts important employee behaviours such as staff turnover, absenteeism, or organisational citizenship or extra-role behaviour, and performance (Steers, 1977; Mathieu \& Zajac, 1990; Allen \& Meyer, 1996; Meyer, Stanley, Herscovitch, \& Topolnytsky, 2002; Gelade \& Gilbert, 2006). Furthermore, when aggregated to the organisational sub-unit level, high levels of commitment are associated with improved levels of customer satisfaction and sales achievement (Gelade \& Young, 2005).

Organizational commitment has become an issue of great importance to be dealt with, because it helps to increase employee performance (Shore \& Martin, 1989; Meyer, Paunonen, Gallatly, Goffin \& Jackson, 1989; Meyer, Allen \& Smith, 1993; Meyer et al., 2002; Siders, George \& Dharwadkar, 2001; Jaramillo, Mulki, \& Marshall, 2005) and also helps to minimize turning up late to work, absenteeism, and leaving or quiting the organisation. Although organisational commitment was initially conceived as a reflection of observed behaviours, Becker (1960) and Porter, Steer, Mowday and Boulian (1974) emphasise the longitudinal aspects of organisational commitment and conceptualise this attitudinal view by defining organisational commitment "....in terms of the strength of an individual's identification with and involvement in a particular organization": Such commitment can generally be characterized by at least three factors;

(i) a strong belief in and acceptance of organisation's goals and values;

(ii) a willingness to exert considerable effort on behalf of the organization

(iii) a definite desire to maintain organisational membership" (Hoffman, Inelson,\& Stewart, 2010).

The concept of organizational commitment has become a major focus of a number of studies. However, no comprehensive definition to cover all disciplines has yet been rendered (Morrow, 1983). The foremost reason for this is that researches from different fields of study such as sociology, social psychology and organizational behaviour have dealt with the topic based on their field of study. Hence, it is no surprise that the literature accommodates a variety of different definitions related to organizational commitment (Çöl, 2004).

Employees with high level of organizational commitment have significant contributions to the achievement of the organization under competitive conditions (Feldman \& Moore, 1982). Commitment of employees to the organization and using all their skills and expertise for the advancement of the organization concerned is a significant issue. Establishment may have a preference to work with those with high level of organizational commitment. The reason for this is the belief that challenges encountered on the way to reaching goals may be overcome with such employees. Attributes of employees in terms of organizational commitment is the key guide for the success of a business.

\subsection{Research Questions}

This study sought to answer the following research questions:

1) Will male management level workers who are above five years of job tenure in the private sector report more organizational commitment, compared to their counterparts in the public sector?

2) Will workers who perceive their bosses to be high on interpersonal relations and emancipatory leadership-behaviour identify more with their organizations than workers who perceive their bosses to be low on these two variables?

3) Will workers who perceive their bosses to be low on autocratic/control leadership-behaviour be more involved in their jobs than workers who perceive their bosses to be high on autocratic/control?

4) Will workers who perceive their boss to be high on interpersonal relations, emancipatory and patriotic leadership-behaviour be more loyal to their organizations than workers who perceive their bosses to be low on these variables?

5) Will workers who perceive their bosses to be high on interpersonal relations and emancipatory leadership-behaviour be more committed to their organizations than workers who perceive their bosses to be low on 
these two variables?

\subsection{Significance of the study}

Since this study is designed to evaluate the relationship between organizational factors, leadership-behaviour and workers' organizational commitment in Nigeria. The results provide:

1) What constitutes the perceived disparity between private and public sector workers'commitment to their organizations.

2) What constitutes rganizational and leadership-behaviour antecedent of failing organizational commitment among Nigerian workers.

3) Reasoned argument of how workers interpret or perceive the supervisory behaviours of their supervisors.

4) Support for employee training and leadership career development initiatives to help organisations' shape the future of organisations and industrial efficiency in Nigeria.

\subsubsection{Theoretical Framework}

-Leader-member exchange theory

Leader-member exchange (LMX) theory posited that the types of one-on-one, or dyadic, relationships that develop between the leader and each follower will be somewhat different. The theory is based on the assumption that leaders establish a social exchange relationship with their employees and that the nature of this exchange relationship influences the manner in which the leader treats each individual employee. Lower-quality exchange relationships between a leader and his or her employees are characterized by the leader's use of formal authority and average levels of employee performance. In contrast, high-quality exchange relationships involve mutual trust, support, and loyalty between the leader and his or her employees, enhanced levels of interpersonal attraction (i.e., liking), and bidirectional influence. Thus, employees in high-quality exchange relationships are motivated to exhibit higher levels of commitment, conscientiousness, and loyalty to their leaders in return for more favorable performance appraisals, promotions, and other rewards from their leaders.

Furthermore, in any work group, the leader tends to develop better relationships with a few subordinates (the in-group), while the rest (out-group) receive less attention or concern from the leader. The character of the leader-member exchange can range from low quality, in which the leader and the subordinates have a negative image of one another and the subordinate does not respect or trust the leader, to high quality, in which the leader and the subordinates have a positive view of one another and the subordinates feel that the leader is supportive and provides encouragement. Such difference has been found to affect subordinates' job outcomes such as work performance, loyalty, commitment, attendance and job satisfaction (Kozlowski \& Doherty, 1989; Liden \& Maslyn, 1998; Wayne \& Ferris, 1990; Vecchio \& Boatwright, 2002).

LMX model posited that leaders treat subordinates differently at varying degrees and levels contingent on whether the latter are part of the in-group (high-quality relationship) or out-group (low-quality relationship) (Graen and Scandura, 1987). The theory asserts that leaders do not interact with subordinates uniformly (Graen and Cashman, 1975) because supervisors have limited time and resources. "In-group" subordinates (workers who have positive image of their leaders) perform their jobs in accordance with the employment contracts and can be counted on by the supervisor to perform unstructured tasks, to volunteer for extra work, and to take on additional responsibilities. Supervisors exchange personal and positional resources (inside information, influence in decision making, task assignment, job latitude, support, and attention) in return for subordinates' performance of unstructured tasks (Graen and Cashman, 1975). As a result, research shows that mutual trust, positive support, informal interdependencies, greater job latitude, common bonds, open communication, high degree of autonomy, satisfaction, and shared loyalty exist in high-quality relationship (Dansereau, Graen, and Haga, 1975; Dienesch and Liden, 1986; Graen and Uhl-Bien, 1995). In contrast, subordinates who perform only in accordance with the prescribed employment contract are characterized as "out-group" with limited reciprocal trust and support, and few rewards from their supervisors (Deluga, 1998).

\subsubsection{Leadership-Behaviour and Organisational Commitment}

Various researches have shown that the type of leadership style/behaviour determines the behaviour of subordinates or workers in an organisation. For example, Wysocki and Kepner (2000) in one of such studies reported that leadership styles that see workers as generally motivated by money, resistant to change, lacking in job knowledge, and as a means to an end rather than cooperative and hard work tend to retard employee productivity, effectiveness, satisfaction and organizational commitment. In Nigeria, it has been observed that most managers in organisations 
especially those in the public sector adopt leadership styles that do not encourage initiative, creativity and autonomy of the employees and this has led to organizational inefficiencies (Fagbohungbe, 1981; Omeneki, 1991; Ogunyinka, 1992).

Fagbohungbe (1981) in a similar study used leadership behaviour description and industrial turnover questionnaire to determine the behaviour of work supervisors in Nigeria National Population Commission. In the study, 48 junior workers were instructed to rate the behaviour of their leaders by filling the questionnaires i.e. leadership behaviour description, and industrial turnover questionnaire. The result indicated that democratic style was less associated with high turnover than the autocratic leadership. Tenure and age appears to be a strong predictor of organisational commitment (Fagbohungbe, 1981; Aboloko, 1985).

Ejimofor, (1987) in a similar study found out a significant relationship between organizational commitment and leadership style, particularly with autocratic leadership style. No relationship was found between democratic leadership style and organizational commitment. Meanwhile, a related study conducted by Aboloko reported significant relationship (Aboloko, 1985). This result is not surprising, because it is a reflection of superior supervisory practices in the private sector. Also, Esigbone (2000) in a related study on influence of perceived leadership style on employees' job satisfaction reported that democratic leadership style showed a statistically strong significant positive correlation with job satisfaction, while autocratic leadership style showed a weak relation with job satisfaction. Omeneki (1991) investigated the impact of perceived leadership styles on employee commitment among NITEL workers. The result revealed that there was no significant difference in employees' commitment between workers who perceived their leaders/bosses as democratic or autocratic. There were also no gender differences in workers' commitment. Job tenure was also found not to be related to workers' organisational commitment. Ogunyinka (1992) in similar study, found a positive correlation between democratic leadership style and organisational commitment.

Makoto (1997) also investigated the relationship between 3 leadership behaviours (pressure, planning and maintenance) and subordinate morale, skill level, status and need for autonomy. He concluded that for a subordinate with high status (senior staff) planning is the most effective leadership behaviour, while maintenance is more effective with subordinate with low status. Alarape and Akinlabi (2000) were of the opinion that employees develop their work attitude based on their general perceptions about the actions of their organisations toward them. Such perceptions are formed based on the organizations' policies, procedures and decisions driven by managers. From such perceptions, employees could infer the intentions of the organization toward them and choose to be committed, involved or withdraw their loyalty. Foke (2001), in a similar study investigated the effects of leadership behaviour on job satisfaction, productivity and organizational commitment. The study explored the relationships between five leadership behaviours identified by Kouze and Posner (2002) and the employee outcomes of registered nurses practicing in the general wards, intensive care units and the coronary care unit in an specialist hospital. The study concluded that leadership behaviours and employee outcomes were significantly correlated. The regression results indicated that $29 \%$ of job satisfaction, $22 \%$ of organizational commitment, and $9 \%$ of productivity were explained by the use of leadership behaviour (Foke, 2001).

Laka-Mathebula (2003) investigated the relationship between organisational commitments among 246 employees from 11 institutions of higher learning. There were $45.12 \%$ females and $54.51 \%$ males. The average age of respondents was 41.9 years. Correlation analysis and multiple regressions indicated a weak prediction of organisational commitment. Jaskyte (2004) revealed that for commitment, the combination of leadership behaviours, participation, work control and subordinate relations explained $48.1 \%$ of its variance. Mester, Visser, Roodt, (2003) examined the relationships between leadership styles and organisational commitment, job satisfaction, job involvement and organisational citizenship behaviour among employees of selected engineering company. A sample of 52 leaders and 276 employees participated in the empirical study. The results of a canonical correlation analysis using the rater data indicated that the most prominent relationship was that between transactional leadership and affective commitment. Furthermore, transformational and transactional leadership styles did not correlate significantly with the constructs of job involvement and job satisfaction.

Jaskyte (2004) assessed changes in employees' perceptions of leadership behaviour, job design and organizational arrangements and their job satisfaction and commitment. It was hypothesized that employees' perceptions of organizational arrangements, job characteristics, and leadership behaviour would be related to their job satisfaction and commitment. The result showed that employees' perceptions of leadership behaviour were important predictors of job satisfaction and commitment (Jaskyte, 2004). Avolio, Zhu, Koh and Bhatia (2004) examined whether psychological empowerment mediated the effects of transformational leadership on followers' organizational 
commitment among 520 staff nurses employed by a large public hospital. Results from HLM analyses showed that psychological empowerment mediated the relationship between transformational leadership and organizational commitment. Similarly, structural distance between the leader and followers moderated the relationship between transformational leadership and organizational commitment. Elloy (2005), in a related study, investigated the influence of super-leader behaviours on organisational commitment, job satisfaction and organisation self-esteem among $141 \mathrm{employes}$ in a self-managed work team. The results indicated that teams/groups that were led by a supervisor who exhibited the characteristics of a super-leader had higher levels of organisational commitment, job satisfaction, and organisational self-esteem.

Epitropaki \& Martin, (2005) matched the behaviour of leaders with implicit expectations of their followers and observed that in job satisfaction, commitment to the organization, and well-being of employees improved. This finding suggests that worker-related leadership behaviour is more likely to promote desirable work attitudes in employees. This outcome however is not feasible unless supervisors and managers can establish the preferences of their followers. Fortunately, research indicates that the personality of followers could influence their leadership preferences. Perryer and Jordan (2005) also investigated the influence of two dimensions of leader behaviour (supportive behaviour and extinction behaviour) on organisational commitment among public sector workers. It was found that, while controlling for demographic variables, both extinction and supportive leader behaviour affect organisational commitment. Furthermore, a significant interaction of these two variables was found. This indicates that an increase in supportive leader behaviour together with a decrease in extinction leader behaviour will likely lead to a more than proportionate increase in levels of organisational coomitment.

Leach (2005) in a related study investigatigated the relationships between excecutive leadership and organisational commitment among nurses in acute care hospitals. A cross-sectional, field survey of nurse executives, nurse mangers, and staff nurses was conducted to assess the relationship of nurse executive transformational leadership to organisational commitment. Results revealed an inverse relationships between nurse executive transformational and transactional leadership and alienative (high negative) organisational commitment. Also, a positive association was demonstrated between nurse executive leadership and nurse manager leadership.

Suar, Tewari and Chaturbedi (2006) have shown that subordinates' perception of leadership style has a significant relationship with commitment to the organization and job satisfaction. Several major studies have found a positive relationship between these variables such as Newman (1974), Porter, Campon and Smith (1976), Mathieu and Zajack (1994) and Wilson (1995). Huang, Shi, Zhhang \& Cheung (2006) investigated the impact of participative leadership on psychological empowerment and organisational commitment of 173 employes of two Chinese state-owned enterprises. The study found that participative leadership behaviour was associated with organisational commitment, but not with all four dimensions of psychological empowerment such support, delegation, decision making etc.

Akroyd, Jackowski and Legg (2007) in a related study to determine the predictive ability of selected organisational leadership, work role and demographic variables on organisational commitment gathered data from 3000 full time radiographers. The participants were surveyed by mail regarding their commitment to their employers, leadership within the organisation that employ them, employer support and demographic information. Results indicated that radiographers were found to have only a moderate level of commitment to their employers. Among the factors that significantly affected commitment were the radiographers' educational level, perceived level of organisational support, role clarity and organisational leadership.

Weaver, G., \& Yancey, G.B. (2010) in a related study investigated the impact of dark leadership on organizational commitment and turnover among 80 employees working for a manufacturing company. Results indicated that dark leadership (narcissistic, compulsive leader, paranoid leader, co-dependent leader, passive-aggressive leader) was found to be inversely related to the workers' affective commitment to the organization and to the workers' intent to remain with the organization. Salami, (2002) examined demographic and psychological predictors of organisational commitment outside leaders behaviour 320 employees (male $=170$, female $=150)$, randomly selected from 5 service and 5 manufacturing organizations in Oyo State, Nigeria. Measures of biographical data, emotional intelligence, work-role salience, achievement motivation, job satisfaction and organizational commitment were administered on the sample. Hierarchical multiple regression analysis was used to analyse the data collected. Results showed that emotional intelligence, work-role salience, achievement motivation, job satisfaction and all demographic factors except gender significantly predicted organizational commitment of the workers.

\subsection{Research Hypotheses}

H1: Male management level workers who are above five years of job tenure in the private sector will report more organizational commitment compared to their counterparts in the public sector. 
$\mathrm{H} 2$ : Workers who perceive their bosses to be high on interpersonal relations and emancipatory leadership-behaviour will identify more with their organizations than workers who perceive their bosses to be low on these two variables.

H3: Workers who perceive their bosses to be low on autocratic/control leadership-behaviour will be more involved in their jobs than workers who perceive their bosses to be high on autocratic/control.

H4: Workers who perceive their bosses to be high on interpersonal relations, emancipatory and patriotic leadership-behaviour will be more loyal to their organizations than workers who perceive their boss to be low on these variables.

H5: Workers who perceive their bosses to be high on interpersonal relations and emancipatory leadership-behaviour will be more committed to their organizations than workers who perceive their bosses to be low on these two variables.

\subsection{Operational Definitions of variables}

Leadership: Leadership is the process of influencing the activities of an individual within a group in its effort towards goal achievement in a given situation. It is the process of influencing people so that they will strive willingly and enthusiastically towards the achievement of group goals. In the broad context of this study, leadership is an act of exemplary conduct and self-less service that is capable of inspiring or galvanising subordinates to get things done willfully and efficiently. Leadership in the context of this study is not about personality: it is about behaviour

Perceived Leadership-Behaviour: refers to individual worker's ratings of his/her supervisor or manager's leadership behaviour as measured by Leadership Behaviour Description Inventory. Among the dimensions of leadership behaviour under investigation are those described below?

-Interpersonal Relations Leadership-Behaviour: a dimension of supervisor/manager's leadership behaviour in which the subordinate perceives the supervisor/manager as possessing the following qualities: supportive and enduring relationship, mutual understanding and synchronised interaction. Such a boss is considered as such if he or she was rated high on this attribute, as measured by LBD-35.

-Emancipatory Leadership-Behaviour: a dimension of supervisor/manager's leadership behaviour in which the supervisor/manager is perceived to possess the following qualities: transformational acts, modeling acts, positive exemplary acts, human development acts, societal change acts, and the act of initiating and promoting subordinate's self-development. A boss will be seen as such if greater percentage of subordinates' rated him or her as high in this attribute, as measured by LBD-35.

-Autocratic Leadership-Behaviour: a dimension of supervisor/manager's leadership behaviour in which the supervisor/manager is perceived by subordinates as demonstrating excessive control, refusal to explain actions, blowing-up and criticising, decides in details what work and how work shall be done, puts the welfare of the unit above that of the subordinates. Such a boss is thereby rated by subordinates' as being high in autocratic/control leadership-behaviour.

-Productivity Leadership-Behaviour: a dimension of supervisor/manager's leadership behaviour in which the manager/supervisor is perceived by subordinates to demonstrate excellent, nurturant-task and participative leadership; pushe the staff for greater effort, emphasise meeting deadline for duties; work subordinate to capacity; encourage attendance at relevant training courses; and provide opportunities for skill development on the job.

-Patriotic Leadership-Behaviour: a dimension of supervisor/manager's leadership behaviour in which the supervisor/manager is perceived by subordinates to demonstrate fairness, trusting relationship, organizational justice, tolerance of diverse beliefs, ability to transform good will into vision and hope for better life.

\section{Research Method}

\subsection{Participants}

The participants for this study consisted of employees selected from private and public service organizations located in Lagos and Abuja in Nigeria. There were 285 males (56.5\%), 219 females (43.5\%), out of which 249 (49.4\%) were drawn from private organizations and $255(50.6 \%)$ were drawn from public organizations. Their job tenures with their organizations ranged from (1) to (18) years with a mean tenure of 8.4 years (SD. $=2.13$ ), their ages ranged from 24 to 59 years with a mean age 39.5 years.

Insert Table 1 here 
Specifically, the participants were selected from the following Private and public sector organizations: (i) Public organisation-Nigerian Security Printing \& Minting Company Ltd, NIPOST and Central Bank of Nigeria (CBN), Federal /State Ministries of Health, Works \& Housing, and Education. (ii) Private Organisations- UBA Plc HQ Lagos, Zenith Bank Plc HQ Lagos, WEMA Bank Plc HQ Lagos., IGI (Ind. \& General Insurance) HQ Lagos, OASIS and Cornerstone Insurance HQ Lagos, Express Discount Ltd. Lagos office, The Guardian Newspaper, Matori Lagos office. These organizations were so considered simply because they are human service organization. Organisational practices and service delivery are intangible and requires substantial interpersonal contacts.

\subsection{Sampling Technique}

Participants were selected using simple accidental sampling technique during office hours fin their various offices, while the organizations sampled were selected using purposive sampling technique. A total number of 791 questionnaires were distributed in all the sampled departments. After thorough screening of the questionnaires, only 504 were found fully completed, this giave a response rate of $63.71 \%$.

\subsection{Research Design}

Ex-Post-Factor research designs was used.

\subsection{Instruments}

The new instrument, 10-item Biographic Information Questionnaire (BIQ) and five tested and widely used research measures were employed in data gathering:

1) A 10-item Biographic Information Questionnaire (BIQ) designed to obtain demographic information such as sex, age, tenure, sex of leader, ethnic affiliation of subordinate and that of the manager or supervisor etc.

2) Leadership-Behviours Description Inventory (LBD-Inventory) - LBD-Inventory is a 35-item inventory developed by Akinbode (2011). The items were derived directly from leadership-behaviour description exercise conducted among selected workers. To obtain participants scores on each of the subscales the values of the direct score item of the numbers shaded in the relevant items are added with the values of the reverse items after the number shaded for the reverse scores have been changed from 0,3,2,1 to 01,2,3 respectively. By adding together the scores of both direct and reverse scores for each of the subscales the score obtained for each subscale werewritten beside the letters representing the subscale for record in the test form.

3) Organisational Commitment Scale (OCS): developed by Buchanan (1974) to measure workers organizational commitment: job identification, job involvement and loyalty were used. It has 23 items on a 7-point scale. The author reported a coefficient alpha of $0.86,0.840 .92$ and 0.94 for job identification, job involvement, loyalty and overall test respectively. Cook \& Wall (1980) correlated OCS with Overall Job Satisfaction by Wall, Cook \& Wall (1980) and obtained a concurrent validity coefficient of .62. Mogaji (1997) provided the norms for Nigerian samples and they are: $25.87,28.54,38.90$ and 95.48 . The instrument is on 7-point Likert Scale from 1= strongly disagree to $=7$ strongly agree. There was direct scoring and reverse scoring of the items. Direct score items were added together by summing the values of the numbers shaded in the relevant items of a 7-point Likert scale. For the reverse score items, the values of the number were changed from $1,2,3,4,5,6,7$ to $7,6,5,4,3,2,1$, respectively and these were added together in a reversed manner of the numbers shaded in the relevant items. The results were added to determine the score for the particular scale for each participant. The overall organizational commitment score then give the scores of the three scales for each participant.

\subsection{Procedure}

The seven instruments were stapled together randomly to prevent respondents response set, except the 10-item BIQ that appeared firtst. This was done to prevent response set since there are quite a three surveys to be completed. Meanwhile, prior to questionnaire administration, consultations were held with the head of human resource units and Departments in each of the organisations selected to describe the study and survey instruments and the motive of the research. This initial attempt was taken to facilitate and obtain official permission and informed consent from collaborating organisations to use their employees for the study. These steps were considered essential because of the seeming difficulties inherent in seeking cooperation and assistance from busy workers.

Final collection of the data was carried out by administering the instruments (questionnaires) to employees in the sampled organisations, with the assistance of two trained research assistants. Respondents were also asked to answer several demographic questions indicating their unique personal data. Names of participants were declared optional, so respondents were assured that their responses were completely anonymous. Only those respondents who were currently employed on full time participated in the study. 


\section{Analysis of Results}

In order to examine organizational commitments, mean and standard deviation of scores of participants were computed, by gender, management level and organizational type. The result is presented in Table 2 below.

\section{Insert Table 2 here}

The result in Table 2 indicated that organizational commitment of male workers (mean $=98.3$; $\mathrm{SD}=22.3$ ) was higher than that of female (mean $=95.6 ; \mathrm{SD}=18.8$ ). Organisational commitment was higher among public sector workers $($ mean $=97.9 ; \mathrm{SD}=19.5$ ) compared to private sector workers (mean $=96.4 ; \mathrm{SD} 22.2$ ). Also, job involvement appears to be relatively similar, except that mean job involvement for females was higher than that of their male's counterparts. Mean OCB was higher for males (Mean $=71.18$; $\mathrm{SD}=11.59)$, senior management (Mean $=70.6 ; \mathrm{SD}=13.52$ ), and public organizations (Mean $=70.5 ; \mathrm{SD}=12.40$ ). Given the relative large standard deviations reported, the result shows a great deal of variability in workers' organizational commitment. Loyalty of male workers in public workers particularly among the senior management level cadre was higher than their counterparts in the private sector. It appears from the results that there seem to be no significant difference in workers self report of job identification and job involvement.

\subsection{Hypotheses Testing}

In order to investigate the influence of some selected organizational factors on organizational commitment among the sampled workers, Logistic regression analysis was computed. The result of the analysis is presented in Table 3 .

\section{Insert Table 3 here}

Result of logistic regression presented in Table 3, eventhough not significant, revealed a positive progression in the observed organizational commitment from organizational type to job tenure. By implication, this result revealed that workers under five years are about 1.05 times more commited to their organization than workers who have spent more than five years. Similarly, males reported higher commitment (at least 1.05 times) as compared to their female counterparts. This progression is followed closely by the management level of workers. It was clearly revealed that junior reported higher commitment than senior management level workers for at least about 1.03 times. However, organizational type did not significantly influence organisational commitment. Hypothesis 1 which stated that male management level workers who are above five years of job tenure in the private sector will report higher organisational commitment compared to their counterpart in the public sector is hereby rejected

In order to investigate the influence of perceived interpersonal relations and emancipatory leadership behavior on organizational commitment, Pearson product moment correlation analysis was computed. The means, standard deviations and inter-correlation values are presented in Table 4.

\section{Insert Table 4 here}

The result indicated that interpersonal relations, emancipatory, autocratic, productive and patriotic leadershipbehaviour had significant positive correlations with organizational commitment variables (Job identification, Job involvement and Job loyalty).

Further, the influence of perceived leadership-behaviour on organizational commitment was examined by implementing a multiple regression analysis. The result of this analysis is presented in Table 5.

Insert Table 5 here

The result indicated that interpersonal relations significantly contributed about $19.9 \%$ of the total variance of the observed job indentification (Beta $=.199, \mathrm{t}=2.888$, at $\mathrm{p}<0.05$ ) as measured by LBD-35. Similarly, emancipatory leadership-behaviour contributed $17.2 \%$ to the prediction of workers' job identification (Beta $=.172, \mathrm{t}=2.928$, at $\mathrm{p}<0.05$ ). Meanwhile, autocratic/control, productive and patriotic leadership-behaviour did not produce significant results as far as prediction of job identification is concernd. However, the joint influence of leadership behaviours yielded significant coefficient of regression $\mathrm{R}^{2}=.164$, $(\mathrm{p}<0.05$ and F-ratio $=19.513$, at $\mathrm{p}<0.05)$. This implies that interpersonal relations and emancipatory leadership-behaviour jointly contributed about $16.4 \%$ of the observed variance in job involvement. Therefore, it follows that $83.6 \%$ of the variance in job identification is accounted for by other factors apart from leadership behaviour.

\section{Insert Table 6 here}

Result presented in Table 6 indicated that only autocratic/control significantly contributed to the observed variance in job involvement $($ Beta $=.181, \mathrm{t}=.2 .489$ at $\mathrm{p}<0.05 ; \mathrm{F}$-ratio $=5.482$, at $\mathrm{p}<.05)$. Interpersonal relations, emancipator, productive and patriotic leadership-behaviours did not contribute to the prediction of workers' job involvement 
respectively.The joint influence of leadership-behaviours, however, yielded significant coefficient of regression $\mathrm{R}^{2}=$ $0.052(\mathrm{p}<0.05)$, accounting for only about $5.2 \%$ of the observed variance in job involvement.

\section{Insert Table 7 here}

Table 7 shows that interpersonal relations significantly contributed to the obsereved variance in workers' job loyalty $($ Beta $=.288, \mathrm{t}=3.977$, at $\mathrm{p}<0.05 ; \mathrm{F}$-ratio $=8.182$, at $\mathrm{p}<.05)$. Similarly, autocratic/control leadership-behaviour contributed to the prediction of workers' job loyalty in a negative direction (Beta $=-.154, \mathrm{t}=-2.143$, at $\mathrm{p}>0.05$ ). This result implies that autocratic/control accounted for about $15.4 \%$ of job disloyalty in the workplace. The joint influence of this perceived leadership-behaviours only accounted for about $7.6 \%$ of the observed variance in job loyalty. Therefore, it follows that 92 our. $4 \%$ of the variance in job loyalty is accounted for by other factors apart from leadership-behaviour.

\section{Insert Table 8 here}

The result as presented in Table 8 indicated that interpersonal relations significantly contributed to the variance in organizational commitment $($ Beta $=.193, t=.2 .722$, at $\mathrm{p}<0.05)$. Meanwhile, emancipatory leadership-behaviour did not contribute to the prediction of workers' organizational commitment (Beta $=.102, t=1.696$, at $\mathrm{p}>0.05$ ). Similarly, autocratic/control yielded insignificant result $(\mathrm{Beta}=.071, \mathrm{t}=1.006$, at $\mathrm{p}>0.05)$. Also, productive and patriotic leadership-behaviour failed to predict workers organizational commitment. However, joint influence of leadership-behaviours, yielded significant coefficient of regression $\mathrm{R}^{2}$ and fratio $\left(\mathrm{R}^{2}=.116\right.$, at $\mathrm{p}<0.05$, and F-ratio $=$ 13.027 , at $\mathrm{P}<0.05$ ) respectively. This result implies that only about $11.6 \%$ of the observed variance in organizational commitment is accounted for by theb joint influence leadership-behaviour under reference.

\section{Discussion}

Hypothesis 1 which stated that male management level workers who are above five years of job tenure in the private sector will report higher organizational commitment compared to their counterpart in the public sector was rejected. Result of logistic regression revealed a positive progression in the observed organizational commitment from organizational type to job tenure. Workers under five years are about 1.05 time's higher commited to their organization than workers who have spent more than five years. Similarly, males reported more commitment (at least 1.05 times) as compared to their female counterpart. Also, result indicated that junior workers reported more commitment compared to senior management level workers for at least about 1.03 times. Surprisingly, type of organizational of workers did not significantly influence organizational commitment. It is however established that male workers, particularly at both private and public sector workplace reported higher organizational commitment compared to their female counterparts. This result is incontrast to that of Omeneki (1991) which reported that there were no gender differences in workers' commitment. This result extended the findings of Fagbohungbe (1981) in a similar study which reported that Tenure appears to be a strong predictor of organisational commitment and that of Salami (2002) which reported that demographic and psychological were significant predictors of organisational commitment.The findings is also consistent with that of Aboloko (1985). Omeneki (1991) findings that tenure was related to workers' organisational commitment were also confirmed by the current finding. The findings contrasted the report of Ogunyinka, (1992) that job tenure does not in any way influence workers' commitment. Obviously, the reasons for this finding are not far fetched considering the ever increasing standard of living with its attendant declining disposable income and general unemployment. People, particularly men tend to devote much attention to whatever they have as a means of lifelihood for the fear of unknown, hence workers cannot afford not be commitment.

Hypothesis 2 which stated that Workers who perceive their boss to be high on interpersonal relations and emancipatory leadership-behaviour will identify more with their organizations than workers who perceive their boss to be low on these two variables was accepted. The result indicated that interpersonal relations significantly contributed about $19.9 \%$ of the total variance of the observed job indentification. Similarly, emancipatory leadership-behaviour contributed $17.2 \%$ to the prediction of workers' job identification. Expectedly, autocratic/control, productive and patriotic leadership-behaviour did not produce significant results as far as prediction of job identification is concern. Combinatorial influence of the predictor variable predicted about $16.4 \%$ of the total observed variance in job identification. This finding supported the report of Fagbohungbe (1981) that democratic style was less associated with high turnover than the autocratic leadership.

Hypothesis 3 which stated that workers who perceive their boss to be low on autocratic/control leadership-behaviour will be more involved in their jobs than workers who perceive their boss to be high on autocratic/control was rejected. Surprisingly, result indicated that only autocratic/control significantly contributed $19.3 \%$ to the observed variance in 
job involvement. Interpersonal relations, emancipatory, productive and patriotic leadership-behaviours did not contribute to the prediction of workers' job involvement. Joint influence of leadership-behaviours could only predict about $5.2 \%$ of the observed variance in job involvement. This result extended the finding of Weaver \& Yancey (2010) that dark leadership is inversely related to the workers' affective commitment (emotional involvement) to the organization and to the workers' intent to remain with the organization.

Hypothesis 4 which stated that workers who perceive their boss to be high on interpersonal relations, emancipatory and patriotic leadership-behaviour will be more loyal to their organizations than workers who perceive their boss to be low on these two variables was accepted. Result showed that interpersonal relations significantly contributed about $28.8 \%$ to workers job loyalty. Meanwhile, autocratic/control leadership-behaviour had an inverse function, and contributed $15.4 \%$ of workers disloyal and sabotage behaviours. This finding supported the finding of Kouze \& Posner (2002) which concluded that leadership behaviours and employee outcomes were significantly correlated. The finding is also consistent with Foke (2001) that reported leadership behaviour as significant predictors of organizational commitment.

Hypothesis 5 which stated that Workers who perceive their boss to be high on interpersonal relations and emancipatory leadership-behaviour will be more committed to their organizations than workers who perceive their boss to be low on these two variables was supported. Result indicated that interpersonal relations and emancipatory leadership behaviour had significant positive correlations with organizational commitment variables (job identification, job involvement and job loyalty). Interpersonal relations contributed about $19.3 \%$ of the observed variance in workers organizational commitment. Emancipatory leadership-behaviour contributed $10.2 \%$ workers' organizational commitment, while autocratic/control contributed only $7.1 \%$ of the obsereved variance. Also, productive and patriotic leadership-behaviour did not predict workers organizational commitment, the finding underscores the emergence of various sharp practices in the Nigerian organization in recent times. Perceived leadership-behaviours accounted for about $11.6 \%$ of the observed variance in organizational commitment. The finding therefore exemplified the position of House (1971) Path-goal theory which emphasizes the relationship between the leaders' style and the characteristics of the subordinates and the work setting. The theory proposed that subordinates accept a leader's behaviour when they perceive that that behaviour will lead to their present and future job satisfaction and motivation. It states also that the leader's behaviour can motivate subordinates if it is perceived by them as being capable of making it possible for them to achieve their organizational goals. That is, the scope of the job and the characteristics of subordinates moderate the relationship between a leader's behaviour/style and subordinates' job outcomes: performance, satisfaction, commitment involvement etc.

The finding is also consistent with the findings of Aboloko (1985), Ejimofor (1987), and Esigbone (2000) that reported significant relationship between organisational commitment and leadership style. The finding supported the findings of Jaskyte, 2004; Avolio, Zhu, Koh and Bhatia, 2004; Elloy, 2005) that employees' perceptions of leadership behaviour were important predictors of psychological empowerment and organisational commitment, which revealed that a combination of leadership behaviours, participation, work control and subordinate relations explained about $48.1 \%$ of the total variance in organisational commitment. The finding is at variance with the finding of Omeneki (1991) and Laka-Mathebula, which reported a weak relationship between leadership behaviours and organisational commitment.

The import of this findings is far reaching bearing in mind the seeming divergence of opinions among researchers about organisational; commitment of Nigerian workers. Some researchers believed that Nigerian workers are not totally committed to their organizations (Fagbohungbe, 1981, Eze, 1985; Munene, \& Azuka, (1991). Others believed that they are committed to organizational goals whereas the organizations do not show commitment to the plight of the workers (Alarape \& Akinlabi, 2000). They believe that organizational commitment reflects one side of the reciprocal relationship between the employer and the employee and as such each party has to play its role. While, it is true that most organizations in Nigeria have experienced and are experiencing restructuring, reengineering, and downsizing which create a sense of job insecurity among the workers arising from government's economic reforms, the cuurent finding is, however turning management searchlight to leadership atmosphere in the Nigerian organisations. Indeed some researchers found that organizational commitment is a function of several variables such as job satisfaction, motivation, participative decision making, organizational support, financial reward, communication, promotion prospects, and leadership styles (Alarape \& Akinlabi, 2000; Brown, 2003; Salami \& Omole, 2005). From this study it is now known that the meaning underlying supervisory or leadership behaviour among the subordinates' is a strong factor in predicting organisational commitment among Nigerian workers. 


\section{Conclusion}

The importance of leadership and dispositional variables to the dynamics of the workplace behaviour has made it one of the most widely discussed and researched topics in industrial/organizational psychology and management particularly in recent times. The leadership behaviours of bosses as perceived by the subordinates do not only have implications for followership, but also specifically, to subordinate's behavioural dispositions to work. The current study posited that it is not probably arguable that personality comes to play in workplace behaviour. Findings from this study seem to have highly profound and demonstrable quality exchange relationships between boss and subordinates as key factors in promoting effective followership in the workplace in Nigeria.

\subsection{Implications of findings}

The findings from this study are useful in understanding that job behaviour is best explained in terms of personal factors, environmental influence (i.e. leadership environment, organizational factors, reward system etc.), that continually interact. The findings will therefore be very useful to human resource practitioners in assessing leadership failure in organizations, using the leadership behaviour description scale developed as a springboard for developing appropriate intervention program on leadership. In the light of this, the frustrated worker may be assisted to modify his/her behaviour and seek reinforcement for other learned behaviour. In other words, his performance standard may be modified by his experiences with the environment (e.g. effective leadership). He may pick interest in the quality of psychological relationship between himself, the manager/supervisor and co-workers hence regain his original performance standards. This will be possible if the leader creates an atmosphere that:

(i) model the way

(ii) inspire a shared vission

(iii) involve the workers and relevant others

(iv) challenge the process

(v) provide information and training about action

(vi) incorporate likely results of action in advise

(vii) Enables others to act

(viii) point out strengths; using persuasion and encouragement

(ix) approach behaviour change in small steps to enhance subordinate's self-efficacy

(x) show exemplary act to encourage the heart

(xi) provide incentives, rewards, praise and encourage self-reward

(xii) decrease possibility of negative responses that deter positive change

\subsection{Limitations and Future Directions}

One prominient limitation to this study is that the study due to time constraint, did not consider ethnic factors which tend to override formation and implementation of effective policies and promotion of divergent opinion groupings in both public and private sector organisations in Nigeria. Another limitation has to do with the sample size of 504 participants. Increasing the sample size substantially in a future study will not only ensure a wider spread of the behavioural domain studied but also the external validity of the findings. An interesting question is whether the relationships found in this study in a Nigerian context also hold true for other Non-English speaking cultures. Thus, future studies may examine the relationships between the variables under investigation in other Non-English speaking cultures.

\subsection{Recommendations}

The following recommendations are offered for practical applications:

- Organizations should, as matter of utmost concern, institute carreer plans and development policies that incorporate headship and leadership training for management position. Such training and development programme should emphasise; mentoring, interpersonal relations, joint development goals.

- It is hereby recommended in strong term that team building programme to stimulate and encourage high-quality exchange boss-subordinate/coworkers relationships should be instituted.

- A corporate culture should be built to allow bosses (supervisors and managers) to sufficiently: 


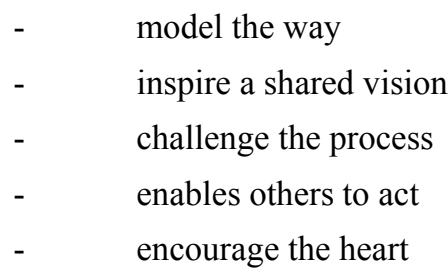

\section{References}

Aboloko, M.O. (1985). "Organisational commitment among Nigerian workers: A comparative study". Unpublished M.Sc Project, Dept. of Psychology, University of Lagos: Lagos.

Agarwal, S., Decarlo, T.E., \& Vyas, S.B. (1999). Leadership behavior and organizational commitment: Acomparative study of American and Indian salespersons. Journal of International Business Studies, 30(4), $724-741$. http://dx.doi.org/10.1057/palgrave.jibs.8490836

Ahmed, S.A. (1985). "The effects of leadership styles on the productivity of workers at Tate \& Lyle Nig. Ltd. Oyo". An unpublished Masters Project, University of Lagos: Lagos.

Akinbode (2011). Development and Validation of a Multi-dimensional Leadership Style Questionnaire. African Journal for the Psychological Studies of Social Issues. 14(1). 57-81.

Akroyd, D., Jackowski, M.B., \& Legg, J. (2007). “Factors affecting radiographers' organisational commitment". Radiologic Technology, 78, 467-475.

Alarape, A.I. \& Akinlabi, F.M (2000). "Influence of perceived organizational support and discretionary treatment on work attitude of industrial workers". African Journal for the Psychological Study of Social Issues, 5(1), 23-36.

Allen, N. J., \& Meyer, J. P. (1990). "The measurement and antecedents of affective, continuance, and normative commitment to the organization." Journal of Occupational Psychology, 63, 1-18. [Online] Available: http://dx.doi.org/10.1111/j.2044-8325.1990.tb00506.x

Allen, N. J., \& Meyer, J. P. (1996). “Affective, continuance, and normative commitment: An examination of construct validity". Journal of Vocational Behavior, 49, 252-276. http://dx.doi.org/10.1006/jvbe.1996.0043

Alo, O.I. (1982). A look at the Myth of the unmotivated worker. In Ejimofor, P.N.O \& Aniagoh, V. A Eds.) Managing the Nigerian worker, Longman Nig. Ltd., 55-61.

Avolio, B.J., Zhu, W., Koh, W \& Bhatia, P (2004). "Transformational leadership and organisational commitment: Mediating role of psychological empowerment and moderating role of structural distance". Journal of Organizational Behavior, 25, 951-968. http://dx.doi.org/10.1002/job.283

Barrick, M.R. \& Mount, M.K. (1991). "The Big-Five personality Dimensions and job performance A meta-analysis". Personnel Psychology, 44, 1-26. http://dx.doi.org/10.1111/j.1744-6570.1991.tb00688.x

Berker, H.S. (1960). Notes on the concept of commitment. American Journal of Sociology, 66, 32-40. http://dx.doi.org/10.1086/222820

Bordia, P., \& Blau, G., (1998). Pay referent comparison and pay level satisfaction in private versus public sector organizations in India. International Journal of Human Resource Management, 9, $155-167$. http://dx.doi.org/10.1080/095851998341242

Buchanan, B. (1974). "Building organizational commitment: The socialization of managers in Work organization". Administrative Science Quarterly, 19, 533-546. http://dx.doi.org/10.2307/2391809

Çöl, G. (2004). Örgütsel baglılık kavramı ve benzer kavramlarla iliskisi._s, Güç Endüstri _liskileri ve_nsan Kaynakları, 6 (2): 31-45.

Dansereau, F., Jr., Graen, G., \& Haga, W. J. (1975). “A vertical dyad linkage approach to leadership within formal organizations: A longitudinal investigation of the role making process". Organizational Behavior and Human Performance, 13, 46-78. http://dx.doi.org/10.1016/0030-5073(75)90005-7

Deluga. R.J. (1998). "Leader-member exchange quality and effectiveness ratings: The role of subordinate-supervisor conscientiousness similarity". Group and Organisation Management, 23, $189-216$. http://dx.doi.org/10.1177/1059601198232006

Dienesch, R.M., \& Liden, R.C. (1986). "Leader-member exchange model of leadership: A critique and further development". Academy of Management Review, 11, 618-634. 
Dunham-Taylor, J. (2000). "Nurse executive transformational Leadership found in participative organizations". Journal of Nursing Administration, 30(5): 241-250. http://dx.doi.org/10.1097/00005110-200005000-00005

Ejiomofor, B.I. (1987). Organisation commitment as a function of leadership styles in Nigerian organisations: A study of three commercial banks in Lagos. Unpublished M.Sc Project, Dept of Psychology, Lagos: University of Lagos.

Elloy, D.F. (2005). "The influence of superleader behaviours on organization commitment, job satisfaction and organisational self-esteem in a self-managed work team". Leadership and Organisational Development Journal, 26 (2), 120-127. http://dx.doi.org/10.1108/01437730510582554

Endler,N.S \& Magnusson, D.(1976). "Toward an interactional psychology of personality". Psychological Belletin, 83, 956-974. http://dx.doi.org/10.1037/0033-2909.83.5.956

Epitropaki, O., \& Martin, R. (2005). "From ideal to real: A longitudinal study of the role of implicit leadership theories on leader-member exchanges and employee outcomes". Journal of Applied Psychology, 90, 659-676. http://dx.doi.org/10.1037/0021-9010.90.4.659

Esigbone, E.M. (2000). "Influence of Perceived Leadership Style on Employee's Job Satisfaction". B.Sc Research Project, Department of Psychology, University of Lagos.

Eze. N. (1994). "Leadership and development in Africa: A social-psychological analysis". In Sabour, M. (Ed), Perspectives in Development: Voice from the South. Finland, Joensuu: University of Joensuu Press, Chap.5, 65-86.

Eze, N. (1983). "Work motivation, job satisfaction and involvement in Nigeria organisations". A keynote lecture presented at the first National conference of the Association of Nigerian Industrial Organaisational Psychologist, Lagos: University of Lagos.

Eze, N. (1985). Motivation and attitudes as correlates of decision-making in MNigerian organizations. In Okpara, E (Ed.) Psychological strategies for national development, University of Benin: Nigerian Psychological Association.

Eze, N. (1988). "A study of leadership in Nigerian organizations." ASCON Journal of Management, 7(1\&2), 95-102.

Eze, N. (1995). Human Resource Management in African -Problems and Solutions. Zomex Press: Lagos.

Eze. N. (1994). "Leadership and development in Africa: A social-psychological analysis". In Sabour, M. (Ed), Perspectives in Development: Voice from the South. Finland, Joensuu: University of Joensuu Press, Chap.5, 65-86(b).

Fagbohungbe, O.B (2002). Testing side-bets theory using job tenure, job involvement and organisational commitment. Journal of School of Management and Business Studies, 1(1), 30-39.

Fagbohungbe, O.B. \& Longe,S.O. (2003). An introduction to psychology concepts and principles. Lagos: Ade-ola Printing Press Ltd.

Fagbohungbe, O.B. (1981). Industrial Turnover as a function of leadership pattern in Nigerian organization. $A n$ unpublished Masters Project, Dept of Psychology, University of Lagos: Lagos.

Fagbohungbe, O.B. (2009). Personnel or human resoursce managemen: The repository for human resource utilization $\left(2^{\text {nd }} E d\right)$. Lagos: Olas Ventures.

Feldman, A.S., \& Moore, W.E. (1982). Labor commitment and social change in developing areas. Connecticut: Grenwood Press Publishers.

Foke, C. L.J. (2001). "Leadership behaviours: effects on job satisfaction, productivity and organizational commitment". Journal of Nursing Management, 9, 191-204. http://dx.doi.org/10.1046/j.1365-2834.2001.00231.x

Gelade, G. A., \& Young, S. (2005). "Test of a service profit chain model in the retail banking sector". Journal of Occupational and Organizational Psychology, 78, 1-22. http://dx.doi.org/10.1348/096317904X22926

Gelade, G.A. \& Gilbert, P. (2006). "National differences in organisational commitment: Effect of economy, product of personality or consequence of culture. Journal of cross-cultural Psychology, 37(5), 542-556. http://dx.doi.org/10.1177/0022022106290477

Graen, G. B. \& Ul-Bien, M. (1995). "Relationship-based approach to leadership: Development of leader-member exchange (LMX) theory of leadership over 25 years: Applying a multi-level multi-domain perspective". Leadership Quarterly, 6(2), 219-247. http://dx.doi.org/10.1016/1048-9843(95)90036-5

Graen, G.B. \& Scandura, T.A. (1987). Toward a psychology of dyadic organizing. In B.M. Staw \& L.L. Cummings (eds). Research in organisational behaviour. Greenwich, CT: JAI Press. 
Graen, G., \& Cashman, J. F. (1975). A role-making model in formal organizations: A developmental approach. In J. G. Hunt \& L. L. Larson (Eds.), Leadership frontiers (pp. 143-165). Kent, OH: Kent State University Press.

Helgesen, S. (1990). The female advantage: Women's ways of leadership. New York, N.Y.: Currency and Doubleday.

House, R. J. (1971). “A Path Goal Theory of leader effectiveness”. Administrative Science Quarterly, 16, 321-338. http://dx.doi.org/10.2307/2391905

Howard, P.J., \& Howard, J.M. (2000). The big-five quick start: An introduction to the five-factor model of personality for human resource professional. [Online] Available: http://www.centacs.com/quikindx.htm. Retrieved September 6, 2007.

Huang, X., Shi, K., Zhhang, Z. \& Cheung, Y.L. (2006). "The impact of participative leadership behaviour on psychological empowerment and organisational commitment in Chinese satea owned enterprise: the moderating role of organisational tenure". Asia Pacific Journal of Management, 23 (3), 345-367. [Online] Available: http://www.springerlink.com/content/4601020u65614w54/ DOI 23/10/20107pm

Jaramillo, F., Mulki, J.P., \& Marshall, G.W. (2005). "A meta-analysis of the relationship between organizational commitment and salesperson job performance: 25 years of research". Journal of Business Research, 58: 705-714. http://dx.doi.org/10.1016/j.jbusres.2003.10.004

Jaskyte, K. (2004). “Assessing Changes In employees' perceptions of leadership behaviour, Job design, and organizational arrangements and their job satisfaction and commitment". Journal of Human Service Management, 27(4), 73-98.

Kouzes, A.J \& Posner, B. Z.(2002). The leadership challenge (3rd Edition), Jossey-Bass: New: York

Kozlowski, S.W \& Doherty, M.L (1989). "In tegration of climate and leadership: Examination of a neglected issue". Journal of Applied Psychology, 74, 546-553. http://dx.doi.org/10.1037/0021-9010.74.4.546

Kraut, A.I. (1970). "The predication of employee turnover by employee attitudes." American Psychological Association, Boston,MM.

Laka-Mathebula, M.R. (2003). Modelling the relationship between organisational commitment, leadership style, human resources management practices and organisational trust. [Online] Available: http://www.upetd.up.ac.za/thesis/available/etd-07062004-112817/.../00thesis.pdf 22/10/20109am

Liden, R \& Maslyn, J. (1998). "Multidimensionality of Leader-member exchange: A empirical assessment through scale development". Journal of Management, 24(1), 43-72.

Limerick, D. (1992). "the shape of a new organization: Implications for human resource management". Asian Pacific Journal of Humamn Resources, 30(1), 38-52. http://dx.doi.org/10.1177/103841119203000106

Makoto, N (1997). "The effects of leader behaviour and some moderators at sport clubs". Japanese Journal of Experimental Social Psychology, 37(2), 203-215. http://dx.doi.org/10.2130/jjesp.37.203

Mathieu, J. E., \& Zajac, D.M. (1990). "A review and meta-analysis of the antecedents, correlates and conseqences of organizational commitment". $\quad$ Psychological Bulletin, 17194. http://dx.doi.org/10.1037/0033-2909.108.2.171

McIntire, M. (2002). How to create enthusiastic, committed employees. [Online] Available: http:/www.imglv.com. $3 / 28 / 2010$.

Mester, C.,Visser, D., Roodt,G. (2003). "Leadership style and its relation to employee attitudes and behaviour." $S A$ Journal of Industrial Psychology, 29 (2), 72-82.

Meyer, J. P., Allen, N.J. \& Smith, C.A. (1993). "Commitment to organizations and occupations: extensions and test of a three-component conceptualization”. Journal of Applied Psychology, 78: 538-551. http://dx.doi.org/10.1037/0021-9010.78.4.538

Meyer, J. P., Paunonen, S., Gallatly. V., Goffin, I. R. \& Jackson, D. N. (1989). “Organizational commitment and job performance: it is the nature of the commitment that counts". Journal of Applied Psychology, 74(1): 152-156. http://dx.doi.org/10.1037/0021-9010.74.1.152

Meyer, J. P., Stanley, D. J., Herscovitch, L., \& Topolnytsky, L. (2002). "Affective, continuance, and normative commitment to the organization: A meta-analysis of antecedents, correlates, and consequences". Journal of Vocational Behavior, 61, 20-52. http://dx.doi.org/10.1006/jvbe.2001.1842 
Meyer, J.P., Paunonen, S.V., Gellaty, I.R., Goffin, R.D., \& Jackson, D.N. (1989). "Organizational commitment and job performance: it's the nature of the commitment that counts". Journal of Applied Psychology, 74: 152-156. http://dx.doi.org/10.1037/0021-9010.74.1.152

Meyer, John P., Allen, Natalie J. \& Smith, Catherine A. (1993). "Commitment to organizations and occupations: Extension and test of a three-component conceptualization". Journal of Applied Psychology, 78(4): 538-551. http://dx.doi.org/10.1037/0021-9010.78.4.538

Meyer, John, P. \& Allen, N.J. (1984). "Testing the ASide-Bet Theory of organizational commitment: Some Methodological considerations". Journal of Applied Psychology, 69: 372-378. http://dx.doi.org/10.1037/0021-9010.69.3.372

Mogaji, A.A. (1997). "Effect of organisational climate on employees commitment, involvement and motivation in some Nigerian manufracturing industries." Unpublished Ph.D Thesis, Dept. of Psychology, University of Lagos.

Morrow, P.C. (1983). Concept redundancy in organisational research: The case of work commitment. Academy of Management Review, 8 (3), 486-500.

Mowday, R., Steers, R. \& Porter, L. W. (1979). "The measurement of organizational commitment". Journal of Vocational Behavior, 14: 224-247. http://dx.doi.org/10.1016/0001-8791(79)90072-1

Mowday, R.T., Porter, L.W. \& Steers, R.M. (1982). Employee-organization linkages: The Psychology of Commitment, Absenteeism, and Turnover. New York: Academic Press

Newman, J.E. (1974). "Predicting absenteeism and turnover: a field comparism of Fishbein's model and traditional job attitude measures." Journal of Applied Psychology, 59, 610-615. http://dx.doi.org/10.1037/h0037334

Nijhof, W.J., De Jong, M.J., \& Beukhof, G. (1998). "Employee commitment in changing organizations: an exploration". Journal of European Industrial Training, 22, 243-248. http://dx.doi.org/10.1108/03090599810224701

Nikolaou, I., Robertson, I. T. (2001). "The Five-Factor model of personality and work behavior in Greece". European Journal of Work \& Organizational Psychology, 10(2), 161-186. http://dx.doi.org/10.1080/13594320143000618

Ogunyinka, A (1992). "Organisational Commitment as a Correlate of Leadership Climate in Private and Public Organisations. Unpublished B.Sc Project: University of Lagos: Lagos.

Omeneki, C.G. (1991). Perceive Leadership Styles as a Correlate of Employees Commitment in Nitel. Unpublished Masters Project, Dept of Psychology, Lagos: University of Lagos: Lagos.

Porter, L. W., Crampon, W. J., \& Smith, F. J. (1976). Organizational commitment and managerial turnover: A longitudinal study. Organizational Behavior and Human Performance, 15, 87-88. http://dx.doi.org/10.1016/0030-5073(76)90030-1

Porter, L.W.; Steers, R.M.; Mowday, R.T.; \& Boulian, P.V. (1974) Organizational commitment, job satisfaction, and turnover among psychiatric technicians. Journal of Applied Psychology, 1974, 59, 603-609. http://dx.doi.org/10.1037/h0037335

Perryer, C. \& Jordan, C. (2005). "The influence of leader behaviours on organisational commitment: A study in the Australian public sector". International Journal of Public Administration, 28(5\&6), 379-396. http://dx.doi.org/10.1081/PAD-200055193

Salami, S.O. (2008). "Demographic and psychological factors predicting organizational commitment among industrial workers", Anthropologist, 10(1): 31-38.

Salami, S.O. \& Omole, O.A. (2005). Participation in decisionmaking process, incentives and training as predictors of organizational commitment among industrial workers. African Journal for the Psychological Study of Social Issues, 8(2): 210-227.

Shore, L. M., \& Martin, H. J. (1989). Job satisfaction and organizational commitment in relation to work performance and turnover intentions. Human Relations, 42(7): 625-638. http://dx.doi.org/10.1177/001872678904200705

Siders, M.A., George, G., \& Dharwadkar, R. (2001). The Relationship of internal and external commitment foci to objective job performance measures, Academy of Management Journal, 44(3): 570-579. http://dx.doi.org/10.2307/3069371 
Suar, D, Teweri, H.R \& Chaturbedi (2006). "Subordinates' Perception of Leadership Styles and Their Behaviour". Psychology and Developing Societies, 18(1) pp. 95-114. [Online] Available: http://pds.sagepub.com/cgi/content/abtract/18/1/95. Retrieved September 11, 2007.

Udegbe, I.B., Okurame, D.E \& Shenge, N.A (2001). Conception of leadership among communities In Nigeria. In I.B. Udegbe (ed.) Dynamics ofLeadership in Contemporary Nigerian Communities: Ibadan SSRHRN, 27-41.

Vecchio, R. P., \& Boatwright, K. J. (2002). "Preferences for idealized styles of supervision". Leadership Quarterly, 13, 327-342. http://dx.doi.org/10.1016/S1048-9843(02)00118-2

Warr, P.B., Cook, J. \& Wall, T. D. (1979). "Scales for the Measurement of Some Work Attitudes and Some Aspects of Psychological Well-being”. Journal of Occupational Psychology, 27, pp. 465-476.

Wayne, S. J., Shore, L. M., Bommer, W. H., \& Tetrick, L. E, (2002). "The role of fair treatment and rewards in perceptions of organizational support and leader-member exchange". Journal of Applied Psychology, 87, 590-598. http://dx.doi.org/10.1037/0021-9010.87.3.590

Weaver, G., \& Yancey, G.B. (2010). "The impact of dark leadership on organizational commitment and turnover". Kravis Leadership Institute, Leadership Review, 10, 104 - 124.

Wilson, P.A (1985). "The effects of politics and power on organizational commitment of federal executives." Journal of Management, 21, 101-118.

Wysocki, A.F. \& Kepner, K.W. (2000). Human resources management in agric-business. A Publication of the Department of Food and Resource Economic, Florida Cooperative Extension Service, Institute of food and Agricultural science, University of Florida, Gainesville, Florida.

Table 1. Demographic profile of Participants in Percentages

\begin{tabular}{|c|c|c|c|c|c|}
\hline Demographic profile & & $\begin{array}{l}\text { ate } \\
\text { ations. } \\
\text { 249) }\end{array}$ & & 5) & $\begin{array}{c}\text { Total } \\
(\mathrm{n}=504)\end{array}$ \\
\hline $\begin{array}{l}\text { Gender } \\
\text { Male } \\
\text { Female }\end{array}$ & $\begin{array}{l}139 \\
112 \\
\end{array}$ & $\begin{array}{l}48.6 \% \\
51.4 \% \\
\end{array}$ & $\begin{array}{l}146 \\
107 \\
\end{array}$ & $\begin{array}{l}51.4 \% \\
48.6 \% \\
\end{array}$ & $\begin{array}{l}285 \\
219 \\
\end{array}$ \\
\hline $\begin{array}{l}\text { Marital Status } \\
\text { Single } \\
\text { Married } \\
\text { Divorced } \\
\text { Separated } \\
\end{array}$ & & & & & \\
\hline $\begin{array}{l}\text { Management Levels } \\
\text { Junior } \\
\text { Senior }\end{array}$ & $\begin{array}{l}153 \\
98\end{array}$ & $\begin{array}{c}62.2 \% \\
38.0 \%\end{array}$ & $\begin{array}{l}93 \\
160\end{array}$ & $\begin{array}{c}37.8 \% \\
62.0 \%\end{array}$ & $\begin{array}{l}246 \\
258\end{array}$ \\
\hline $\begin{array}{l}\text { Tenure } \\
\text { Under } 5 \text { years } \\
6 \text { years \& Above } \\
\end{array}$ & $\begin{array}{l}196 \\
5 \\
\end{array}$ & $\begin{array}{r}58.0 \% \\
7.9 \% \\
\end{array}$ & $\begin{array}{l}142 \\
58 \\
\end{array}$ & $\begin{array}{c}42.0 \% \\
92.1 \% \\
\end{array}$ & $\begin{array}{l}338 \\
63 \\
\end{array}$ \\
\hline $\begin{array}{l}\text { Age } \\
\text { Under } 20 \\
21-30 \text { years } \\
31-40 \text { years } \\
41-50 \text { years } \\
\text { over } 50 \text { years }\end{array}$ & $\begin{array}{l}0 \\
87 \\
122 \\
30 \\
3 \\
\end{array}$ & $\begin{array}{c}100 \% \\
70.2 \% \\
52.1 \% \\
26.1 \% \\
23.1 \% \\
\end{array}$ & $\begin{array}{l}38 \\
112 \\
85 \\
10 \\
\end{array}$ & $\begin{array}{c}29.8 \% \\
47.9 \% \\
73.9 \% \\
76.9 \% \\
\end{array}$ & $\begin{array}{l}0 \\
125 \\
234 \\
115 \\
13\end{array}$ \\
\hline $\begin{array}{l}\text { Education } \\
\text { WASC/SSCE } \\
\text { Trade/vocational schl. } \\
\text { University } \\
\text { professionals }\end{array}$ & $\begin{array}{l}15 \\
83 \\
64 \\
38 \\
\end{array}$ & $\begin{array}{l}48.4 \% \\
63.4 \% \\
41.3 \% \\
45.8 \% \\
\end{array}$ & $\begin{array}{l}16 \\
48 \\
91 \\
45 \\
\end{array}$ & $\begin{array}{l}51.6 \% \\
36.6 \% \\
58.7 \% \\
54.2 \%\end{array}$ & $\begin{array}{l}31 \\
131 \\
155 \\
83\end{array}$ \\
\hline
\end{tabular}


Table 2. The Mean and Standard Deviation of Scores of Participants Dependent Measures

\begin{tabular}{|c|c|c|c|c|c|c|c|}
\hline \multirow[t]{2}{*}{ Dependent variables } & \multirow{2}{*}{$\begin{array}{l}\text { Descriptive } \\
\text { Statistics }\end{array}$} & \multicolumn{2}{|c|}{ Gender } & \multicolumn{2}{|c|}{$\begin{array}{c}\text { Management } \\
\text { level }\end{array}$} & \multicolumn{2}{|c|}{$\begin{array}{c}\text { Organisational } \\
\text { Type }\end{array}$} \\
\hline & & $\begin{array}{c}\text { Male } \\
\mathrm{N}=285\end{array}$ & $\begin{array}{l}\text { Female } \\
\mathrm{N}=219\end{array}$ & $\begin{array}{c}\text { Junior } \\
\mathrm{N}=246\end{array}$ & $\begin{array}{c}\text { Senior } \\
\mathrm{N}=258\end{array}$ & $\begin{array}{c}\text { Private } \\
\mathrm{N}=249\end{array}$ & $\begin{array}{c}\text { Public } \\
\mathrm{N}=255\end{array}$ \\
\hline \multirow{2}{*}{ Job Identification } & Mean & 27.26 & 27.25 & 27.29 & 27.22 & 27.67 & 26.84 \\
\hline & $\mathrm{SD}$ & 8.91 & 8.78 & 8.18 & 9.18 & 9.03 & 8.36 \\
\hline \multirow{2}{*}{ Job Involvement } & Mean & 27.96 & 26.74 & 26.93 & 26.56 & 26.16 & 27.32 \\
\hline & SD & 7.39 & 7.31 & 7.32 & 7.31 & 7.23 & 7.36 \\
\hline \multirow{2}{*}{ Job Loyalty } & Mean & 45.17 & 44.59 & 43.99 & 45.16 & 43.80 & 45.37 \\
\hline & $\mathrm{SD}$ & 10.49 & 9.54 & 9.10 & 9.92 & 9.54 & 9.49 \\
\hline \multirow{2}{*}{$\begin{array}{c}\text { Organisational } \\
\text { Commitment }\end{array}$} & Mean & 98.29 & 95.60 & 97.54 & 96.73 & 96.37 & 97.87 \\
\hline & SD & 22.25 & 18.82 & 18.74 & 22.72 & 22.16 & 19.50 \\
\hline
\end{tabular}

Table 3. Summary Table of Logistic regression analysis

\begin{tabular}{|c|c|c|c|c|c|c|c|c|}
\hline & \multicolumn{6}{|c|}{ Variables in the Equation } & \multicolumn{2}{|c|}{$\begin{array}{c}\text { 95\% CI for } \\
\text { Exp.(B) }\end{array}$} \\
\hline Variables & $\mathrm{B}$ & SE & Wald & df & Sig & Exp. (B) & Lower & Upper \\
\hline Organizational Type [private] & -.0143 & .2204 & .0042 & 1 & .9482 & .9858 & .6400 & 1.5183 \\
\hline Management Levels [Jnr) & .0323 & .2098 & .0237 & 1 & .8777 & 1.0328 & .6846 & 1.5582 \\
\hline Gender [male] & .0536 & .2033 & .0694 & 1 & .7922 & 1.0550 & .7083 & 1.5715 \\
\hline Job Tenure [under 5yrs] & .0572 & .2885 & .3962 & 1 & .5291 & 1.0588 & .5858 & 1.9140 \\
\hline $\begin{array}{l}-2 \text { Log Likelihood } \\
\text { Cox \& Snell - R^ }\end{array}$ & $\begin{array}{l}548.748 \\
400.999\end{array}$ & & & & & & & \\
\hline
\end{tabular}

Table 4. Summary of Pearson's ' $r$ ' Inter-Correlation Matrix of Leadership-Behaviours and Subordinates Organizational Commitment variabless $(\mathrm{N}=504)$

\begin{tabular}{|c|c|c|c|c|c|c|c|c|c|}
\hline Pearson Correlation & 1 & 2 & 3 & 4 & 5 & 6 & 7 & 8 & 9 \\
\hline [1] Interpersonal relations & 1.00 & & & & & & & & \\
\hline [2] Emancipatory & $.689 * *$ & 1.00 & & & & & & & \\
\hline [3] Autocratic & $.757 * *$ & $.638 * *$ & 1.00 & & & & & & \\
\hline [4] Productive & $.276^{* *}$ & $.274 * *$ & $.299 * *$ & 1.00 & & & & & \\
\hline [5] Patriotic & $.277 * *$ & $.211 * *$ & $.402 * *$ & $.190 * *$ & 1.00 & & & & \\
\hline [6] Job identification & $.372 * *$ & $.352 * *$ & $.339 * *$ & .070 & $.153 * *$ & 1.00 & & & \\
\hline [7] Job involvement & $.198 * *$ & $.160 * *$ & $.222 * *$ & .054 & .064 & $.433 * *$ & 1.00 & & \\
\hline [8] Job Loyalty & $.252 * *$ & $.213 * *$ & $.143 * *$ & .045 & .075 & $.424^{* *}$ & $.337 * *$ & 1.00 & \\
\hline [9] Org. commitment & $.322 * *$ & $.282 * *$ & $.292 * *$ & .085 & $.143 * *$ & $.737 * *$ & $.689 * *$ & $.642 * *$ & 1.00 \\
\hline Mean & 21.85 & 17.49 & 16.12 & 8.92 & 4.80 & 27.25 & 26.74 & 44.59 & 97.13 \\
\hline SD & 7.79 & 4.82 & 4.66 & 2.57 & 1.84 & 8.70 & 7.31 & 9.54 & 20.86 \\
\hline
\end{tabular}


Table 5. Summary of Multiple Regression Analyses Showing the Independent and Joint Prediction of Leadership-Behaviour on Job Identification

\begin{tabular}{|c|c|c|c|c|c|c|c|}
\hline Variables & Beta & $\mathbf{T}$ & $\mathbf{P}$ & $\mathbf{R}$ & $\mathbf{R}^{2}$ & $\mathbf{F}_{\text {ratio }}$ & Sig \\
\hline [1] Interpersonal relations & .199 & 2.888 & $\mathrm{P}<0.05$ & \multirow{5}{*}{.405} & \multirow{5}{*}{.164} & \multirow{5}{*}{$* 19.513$} & \multirow{5}{*}{$\mathrm{p}<0.05$} \\
\hline [2] Emancipatory & .172 & 2.928 & $\mathrm{P}<0.05$ & & & & \\
\hline [3] Autocrtaic/Control & .082 & 1.195 & Ns & & & & \\
\hline [4] Productive leadership & -.064 & -1.473 & Ns & & & & \\
\hline [5] Patriotic Leadership & .041 & .906 & Ns & & & & \\
\hline
\end{tabular}

Dependent variable: Job Identification; ${ }^{*} p<0.05, d f=(5,498), N=504: \mathrm{R}^{2}$ is significant.

Table 6. Summary of Multiple Regression Analyses Showing the Independent and Joint Prediction of Leadership-Behaviour on Job Involvement

\begin{tabular}{|c|c|c|c|c|c|c|c|}
\hline Variables & Beta & $\mathrm{T}$ & $\mathrm{P}$ & $\mathrm{R}$ & $\mathrm{R}^{2}$ & $\mathrm{~F}_{\text {ratio }}$ & Sig \\
\hline [1] Interpersonal relations & 0.069 & .923 & $\mathrm{Ns}$ & \multirow{5}{*}{.228} & \multirow{5}{*}{.052} & \multirow{5}{*}{$* 5.482$} & \multirow{5}{*}{$\mathrm{p}<0.05$} \\
\hline [2] Emancipatory & 0.007 & .119 & $\mathrm{Ns}$ & & & & \\
\hline [3] Autocrtaic/Control & .181 & 2.489 & $\mathrm{P}<0.05$ & & & & \\
\hline [4] Productive leadership & -.015 & -334 & Ns & & & & \\
\hline [5] Patriotic Leadership & -.026 & -552 & Ns & & & & \\
\hline
\end{tabular}

Dependent variable: Job Involvement; ${ }^{*} p<0.05, d f=(5,498), N=504: R^{2}$ is significant.

Table 7. Summary of Multiple Regression Analyses Showing the Independent and Joint Prediction of Leadership-Behaviour on Job Loyalty

\begin{tabular}{|c|c|c|c|c|c|c|c|}
\hline Variables & Beta & $\mathrm{T}$ & $\mathrm{P}$ & $\mathrm{R}$ & $\mathrm{R}^{2}$ & $\mathrm{~F}_{\text {ratio }}$ & Sig \\
\hline [1] Interpersonal relations & .288 & 3.977 & $\mathrm{P}<0.05$ & \multirow{5}{*}{.276} & \multirow{5}{*}{.076} & \multirow{5}{*}{$* 8.182$} & \multirow{5}{*}{$\mathrm{p}<0.05$} \\
\hline [2] Emancipatory & .112 & 1.814 & Ns & & & & \\
\hline [3] Autocrtaic/Control & -.154 & -2.143 & $\mathrm{P}<0.05$ & & & & \\
\hline [4] Productive leadership & -.027 & -.582 & Ns & & & & \\
\hline [5] Patriotic Leadership & .039 & .818 & Ns & & & & \\
\hline
\end{tabular}

Table 8. Summary of Multiple Regression Analyses Showing the Independent and Joint Prediction of Leadership-Behaviour on Organizational Commitment

\begin{tabular}{|c|c|c|c|c|c|c|c|}
\hline Variables & Beta & $\mathrm{T}$ & $\mathrm{P}$ & $\mathrm{R}$ & $\mathrm{R}^{2}$ & $\mathrm{~F}_{\text {ratio }}$ & Sig \\
\hline Interpersonal relations & .193 & 2.722 & $\mathrm{P}<0.05$ & \multirow{5}{*}{.340} & \multirow{5}{*}{.116} & \multirow{5}{*}{ *13.027 } & \multirow{5}{*}{$\mathrm{p}<0.05$} \\
\hline Emancipatory & .102 & 1.696 & Ns & & & & \\
\hline Autocrtaic/Control & .071 & 1.006 & Ns & & & & \\
\hline Productive & -.025 & -.569 & Ns & & & & \\
\hline Patriotic & .044 & .956 & $\mathrm{Ns}$ & & & & \\
\hline
\end{tabular}

Dependent variable: Organizational commitment; ${ }^{*} p<0.05, d f=(5,498), N=504: \mathrm{R}^{2}$ is significant. 